\title{
Dichapetalum stahlii (Dichapetalaceae), a new species from Ecuador
}

\author{
Ghillean T. Prance ${ }^{1}$ (D)
}

Summary. A new species, Dichapetalum stahlii, is described from Los Rios in western Ecuador. It is the ninth species of the genus with fimbriate stipules. A key is provided for the seven known Ecuadorian species of the genus.

Key Words. fimbriate stipules, taxonomy.

When Dichapetalum was revised for Flora Neotropica (Prance 1972) it contained 15 species. Since that time more species have been gradually added (for example, Prance 1988, 1994). In Prance (1997) a key was given for the 26 species then recognised that incorporated the eight species known to have fimbriate stipules. This paper adds a ninth fimbriate species from Ecuador. In the account for the Flora of Ecuador (Prance 1980), three species were known from that country then, but by the time of the checklist of the plants of Ecuador (Prance 1999) six species were known and this paper adds a seventh.

Dichapetalum stahlii Prance, sp. nov. Type: Ecuador: Los Rios, Hacienda Clementina, N slope of Cerro Samama, Pita to Torre, $425 \mathrm{~m}$ alt, $79^{\circ} 20^{\prime} \mathrm{W}, 0^{\circ} 30^{\prime} \mathrm{S}, 26$ May 2006 (fl), B. Ståhl, M. Ehn E S. Pettersen 6641 (holotype $\mathrm{K}$; isotype GUAY).

http:/ /www.ipni.org/urn:lsid:ipni.org:names:77202870-1

Liana, the young branches grey tomentose. Leaves with petioles $10-16 \mathrm{~mm}$ long, tomentellous, terete; lamina $15-21 \times 7.5-9.5 \mathrm{~cm}$, chartaceous, weakly bullate above when dry, pubescent on primary venation and with few scattered appressed hairs above, all venation densely grey-puberulous beneath, rounded to acute at apex, rounded or slightly cordate at base; midrib slightly impressed and puberulous above, prominent and hirsute beneath; primary veins 9 - 11 pairs, plane and puberulous above; prominent and hirsute beneath. Stipules subpersistent, fimbriate, $5-8 \mathrm{~mm}$ long, tomentose. Flowers hermaphrodite; pedicels 1 $3 \mathrm{~mm}$ long, grey-tomentose. Inflorescence borne on pedicels near to junction with lamina, bifurcate, 10 $12 \mathrm{~cm}$ long, spreading, the rachis and branches greytomentose; bracts and bracteoles lanceolate, subpersistent, grey-tomentose, 1 - 2 mm long.; calyx c. $1.5 \mathrm{~mm}$ long, grey-tomentose on exterior and margin, glabrous within, the lobes of about equal size; corolla of 5 lobes, deeply bifid almost to base, glabrous; fertile stamens 5 , alternating with and about equal to corolla lobes; disc of 5 ellipsoid free glands; ovary bilocular or trilocular, with 2 pendulous ovules in each loculus, densely lanate on exterior; style lanate at base, glabrous above, the apex trifid. Fruit trilocular, $2-2.5 \mathrm{~cm}$ long, $1.5-2 \mathrm{~cm}$ broad, exocarp with a short compact yellow-brown pubescence. Figs $1 \& 2$.

RECOGNITION. Dichapetalum stahlii differs from D. stipulatum J.F.Macbr. in the petiolar rather than terminal inflorescence, the longer petioles, and the hispid pubescence of the venation of the leaf underside.

DISTRIBUTION AND HABITAT. Known only in the primary forest of Los Rios Province in Ecuador.

SPECIMENS EXAMINED. ECUADOR: Los Rios, Hacienda Clementina, N slope of Cerro Samama, Pita to Torre, $425 \mathrm{~m}$ alt, 79²0’W, 0³0'S, 26 May 2006 (fl), B. Ståhl, M. Ehn Eं S. Pettersen 6641 (holotype K; isotype GUAY); ibid., 25 Sept. 2005 (fr), Ståhl E Pettersen 6352 (GUAY, K).

NOTES. This new species belongs to the small group of Dichapetalum species with fimbriate stipules. It is close to D. stipulatum, but differs from it and all other species with fimbriate stipules in the petiolar rather than terminal or axillary inflorescence, other differences from D. stipulatum are the longer petioles, and the hispid pubescence of the venation of the leaf underside. It differs from D. bullatum Standl. \& Steyerm. in the longer petioles, the blunter leaf apex and the much less bullate leaves. It differs from D. spruceanum Baill., which also has a petiolar inflorescence, in the fimbriate stipules, the blunt leaf apex and the much more spreading inflorescence with a grey, rather than yellow pubescence.

\footnotetext{
Accepted for publication 21 January 2020. Published online 29 April 2020

1 Royal Botanic Gardens, Kew, Richmond, Surrey, TW9 3AE, UK. e-mail: siriain01@yahoo.co.uk
} 


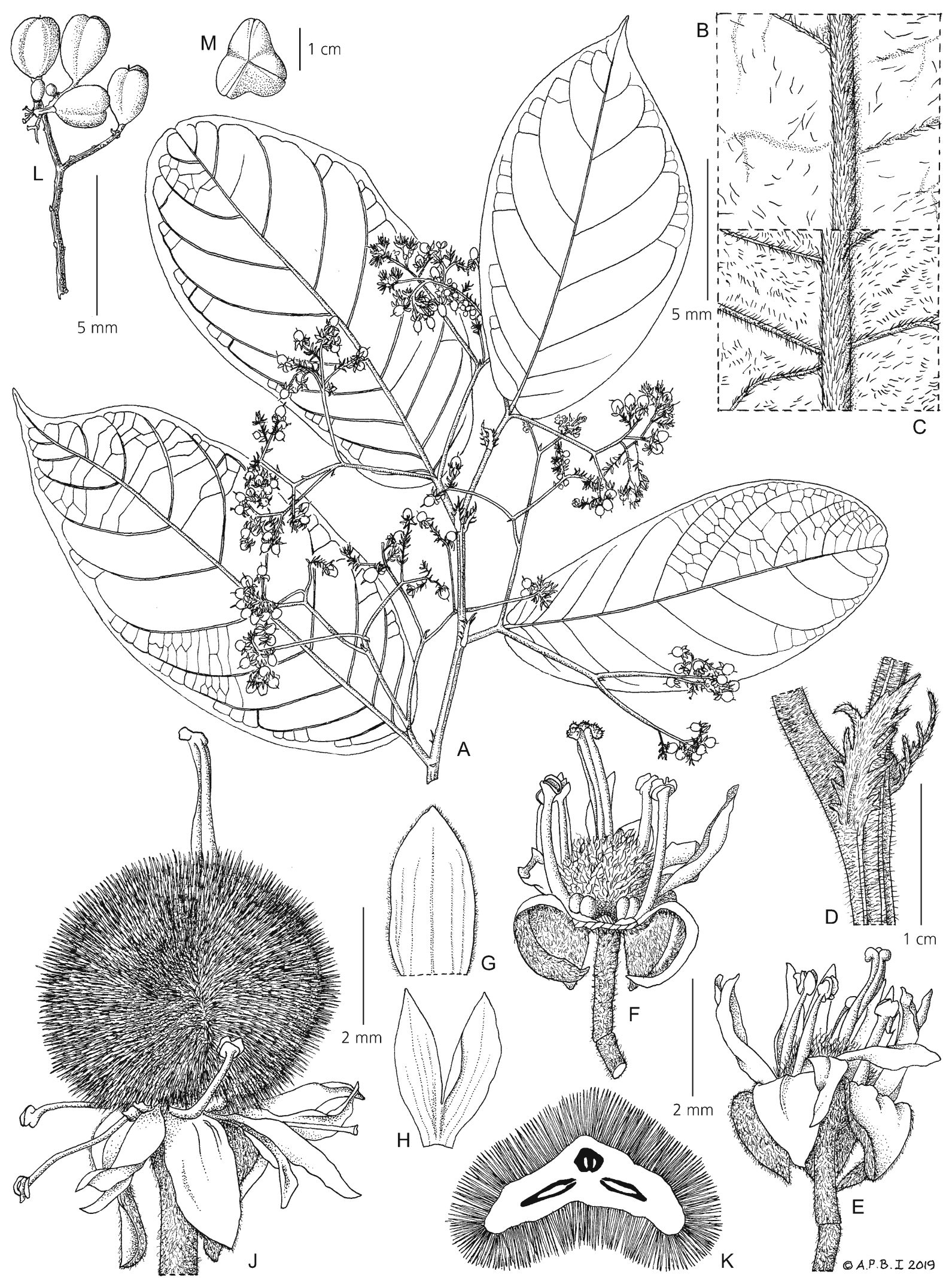

Fig. 1. Dichapetalum stahlii. A habit; B adaxial leaf indumentum; C abaxial leaf indumentum; D pair of fimbriate stipules; $E$ flower, lateral view; F flower with 1 sepal, 2 petals and one stamen removed; $\mathrm{G}$ inner face of sepal; $\mathrm{H}$ inner face of petal; J young fruit with persistent floral parts; $\mathrm{K}$ transverse section of fruit; $\mathrm{L}$ group of mature fruits; $\mathrm{M}$ view of mature fruit showing three locules developed. From Ståhl et al. 6641. DRAWN BY ANDREW BROWN. 


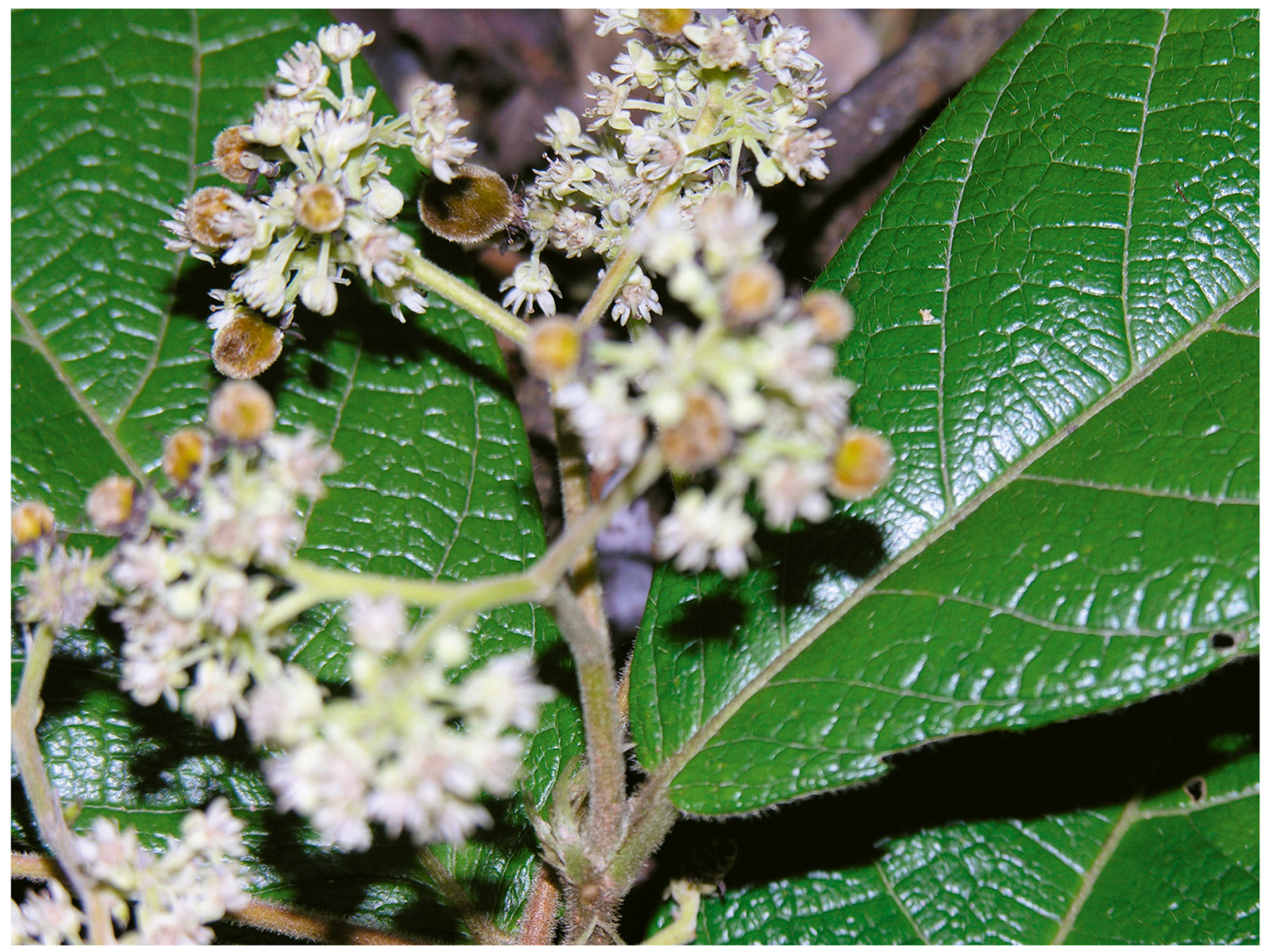

Fig. 2. Dichapetalum stahlii, Ståhl et al. 6641. РнOTOS: B. STÅHL.

\section{Key to species of Dichapetalum from Ecuador}

1. Stipules fimbriate; inflorescence emerging from petioles

2. Leaves 15 - $21 \mathrm{~cm}$ long; acute or very short acuminate at apex, midrib slightly impressed above; petioles 10

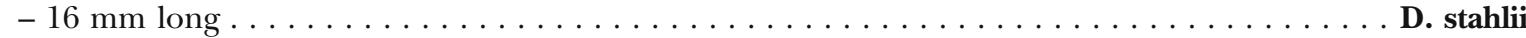

2. Leaves $8-13 \mathrm{~cm}$ long, finely acuminate at apex, the acumen $5-15 \mathrm{~mm}$ long, midrib plane above; petioles

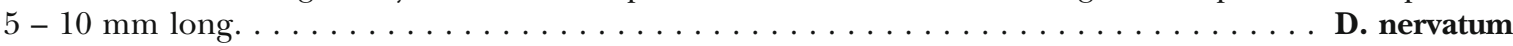

1. Stipules with entire margins; inflorescence terminal or axillary or petiolar.

3. Leaf lamina thickly coriaceous with conspicuously impressed venation on upper surface, appearing slightly bullate when dry; lower surface densely hirsute; liana or shrub . . . . . . . . . . . . D. rugosum

3. Leaf lamina chartaceous to thinly coriaceous; venation of upper surface plane; lower surface hirsute to glabrous; shrub or tree.

4. Leaf lamina , hirsute beneath, margins uneven and undulate; midrib conspicuously impressed for $3 / 4$ of

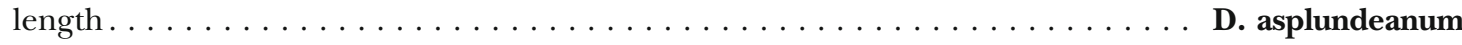

4. Leaf lamina glabrous or with few appressed hairs on venation only, margins entire or slightly undulate; midrib plane or only slightly impressed.

5. Lamina with mucronate or abruptly acute or acuminate apex, the acumen usually curved, the base markedly unequal $\ldots \ldots \ldots \ldots \ldots \ldots \ldots \ldots \ldots \ldots \ldots \ldots \ldots \ldots \ldots \ldots$. spruceanum

5. Lamina tapering to an acute or acuminate apex, the acumen erect, the base equal or only slightly unequal.

6. Leaves $12-28 \times 5-15 \mathrm{~cm}$; petioles $8-32 \mathrm{~mm} \operatorname{long} \ldots \ldots \ldots \ldots \ldots \ldots$. . . . . froesii

6. Leaves $8-16 \times 3.5-9 \mathrm{~cm}$; petioles $4-8 \mathrm{~mm} \operatorname{long} \ldots \ldots \ldots \ldots$. . . . . . . D. . . . . 
Open Access This article is licensed under a Creative Commons Attribution 4.0 International License, which permits use, sharing, adaptation, distribution and reproduction in any medium or format, as long as you give appropriate credit to the original author(s) and the source, provide a link to the Creative Commons licence, and indicate if changes were made. The images or other third party material in this article are included in the article's Creative Commons licence, unless indicated otherwise in a credit line to the material. If material is not included in the article's Creative Commons licence and your intended use is not permitted by statutory regulation or exceeds the permitted use, you will need to obtain permission directly from the copyright holder. To view a copy of this licence, visit http://creativecommons.org/ licenses/by/4.0/.

\section{References}

Prance, G. T. (1972). Dichapetalaceae. Fl. Neotrop. Monogr. 10: $1-84$.

(1980). Dichapetalaceae. Flora of Ecuador 121: 1 - 14. Publishing House of the Swedish Research Councils, Stockholm.

(1988). Three new species of Dichapetalaceae from tropical America. Brittonia 40: 441 - 446. (1994). Four new species of neotropical Dichapetalaceae. Kew Bull. 49: 129 - 136.

(1997). Additions to Neotropical Dichapetalaceae. Kew Bull. 52: 213 - 219.

(1999). Dichapetalaceae, pp. 436 - 437. In: P. M. Jørgensen \& S. León-Yánez, Catalogue of the vascular plants of Ecuador. Missouri Bot. Gard. Press, St Louis.

\section{Publisher's Note}

Springer Nature remains neutral with regard to jurisdictional claims in published maps and institutional affiliations. 